\section{Tuberculosis (Attested Herds) Scheme}

The Minister of Agriculture and Fisheries has amended the Tuberculosis (Attested Herds) Scheme (England and Wales) dated January, 1935, by the issue of a revised scheme, which came into force on June 1. The purpose of the new scheme, which adheres to the principles of the earlier one, is to encourage the addition of herds to the register of herds officially certified to be tuberculosis-free, by the offer of additional financial inducements to owners of cattle herds to qualify for a certificate of attestation. Further information in regard to the scheme may be obtained from the Secretary of the Ministry, Whitehall Place, London, S.W.1.

\section{International Population Congress at Paris}

UNDER the patronage of the International Union for the Scientific Investigation of Population Problems, a congress will be held in Paris for the discussion of these problems on July 29-August 1. The congress is organized by the French National Committee of the Union, under the presidency of $\mathrm{M}$. Adolphe Landry, a former Cabinet Minister. Among the members of the organizing committee may be mentioned, MM. P. Rivet, J. Alquier, H. Bunle, A. Demangeon, M. Huber, R. Legendre, A. Siegfried and other distinguished workers in the field of demography. It is expected that there will be many representative delegations from a large number of countries. From Great Britain there will be members of the British Population Society, presided over by Prof. C. B. Fawcett, and of the Population Investigation Committee, presided over by Prof. A. M. CarrSaunders, and others. America will send Prof. P. K. Whelpton, Dr. Warren S. Thompson and others. Delegations are also expected from Belgium, Czechoslovakia, Denmark, Germany, Holland, Hungary, Italy, Rumania, Sweden, and perhaps India and Japan.

THE subject-matter of the congress is divided into two main groups: quantitative problems, namely, historical demography, contemporary demography, including existing statistics, movements and international migrations, mortality, fertility and so on, and the resulting economic and social problems; and qualitative problems, namely, biometry, ethnology, transmission of characters, eugenics. Two questions are specially put forward for discussion, namely, (1) "De la meilleure méthode pour dégager et mesurer la tendance du mouvement naturel de la population" ; and, (2) "La biométrie différentielle et la biotypologie, comme méthodes pour la classification des individus et des groupes". It is clear that the congress has plenty of work before it. It has been announced that the opening session will be honoured by the presence of the President of the French Republic, M. Albert Lebrun, and will take place at the Maison de la Chimie, 28 rue Saint-Dominique. All inquiries should be addressed to the Congrès International de la Population, 16 rue de l'Estrapade, Paris, V.

\section{Leverhulme Research Fellowships}

Among the list of Leverhulme Research Fellowships and Grants for 1937 are the following, who will carry out their researches at the places indicated:

Research Fellowships: Prof. D. H. Bangham, professor of inorganic chemistry, Egyptian University, Cairo, the wetting of solid surfaces and the phenomena of spreading liquids thereon (Great Britain); Dr. D. Enid Charles, research fellow, Department of Social Biology, London, the mechanism of population decline with special reference to Scottish population problems (University of Aberdeen); Dr. C. W. Davies, senior lecturer in chemistry, Battersea Polytechnic, adsorption at liquid surfaces (University College, London); O. V. S. Heath, research worker, Institute of Plant Physiology, London, carbon assimilation by the green plant (Imperial College, London); Dr. J. de Graaff Hunter, late director, Survey of India, planning and execution of geodetic triangulation of great extent (renewal of present fellowship) (England); G. W. B. Huntingford, farmer, Kenya Colony, member, Nandi Land Trust Board, Government examiner in Nandi language, sociology of the Dorobo, a forest people of Kenya (Kenya); Dr. J. W. H. Lugg, biochemist, Imperial College, London, preparation and amino acid analysis of pasture plant proteins (Imperial College, London); J. P. M. Prentice, solicitor, meteors and meteor streams (England and North Africa); Dr. H. Scott, assistant keeper, Department of Entomology, British Museum, biogeographical research on the fauna of the highlands of South Western Arabia (Arabia); G. Seligman, chairman, British Group, International Commission of Snow, the transition of firn snow into glacier ice (Switzerland); Dr. H. W. Thompson, departmental demonstrator, Old Chemistry Department, University Museum, Oxford, correlation of data derivable from the spectra of polyatomic molecules with chemical problems (Pasadena).

Research Grants : Dr. D. Elliot Dickson, colliery surgeon, Lochgelly, Fife, occupational morbidity in coal miners (Scotland); Dr. E. M. Lind Hendricks, research worker, Imperial College, London, geological research in Cornwall (Cornwall); G. Manley, senior lecturer in geography, University of Durham, the helm wind of the Northern Pennines (England); Dr. R. E. Mortimer Wheeler, keeper, London Museum, origins in northern France of later prehistoric civilizations of Britain (France); Dr. M. Wilson, reader in botany, University of Edinburgh, a comparative study of the diseases of the Douglas fir in Europe and North America (Canada).

\section{Beit Memorial Fellowships}

THE following elections have been made by the trustees of the Beit Memorial Fellowships for Medical Research :

Fourth Year Fellowships (value $£ 500$ a year): Dr. R. P. Cook, to continue his research on cholesterol metabolism in reference to the cause of atheroma in blood vessels (at the Institute of Biochemistry, Cambridge); S. L. Cowan, to continue his research on the neuro-muscular transmission of nervous 
excitation (at the Department of Pharmacology, University College, London); Dr. D. E. Green, to continue his studies on intracellular enzymes and on the influence of vitamin B on oxidation processes (at the Institute of Biochemistry, Cambridge); Dr. M. Jowett, to continue his study of the action of narcotic drugs on the metabolism of the central nervous system (at the Biochemical Laboratory, Cardiff City Mental Hospital).

Junior Fellowships (normal value $£ 400$ a year) : I. A. Anderson, for research on iron analyses of diets of women of the poorer classes at Aberdeen, and studies on the treatment of anæmia (at the Metabolic Research Laboratory, Aberdeen Royal Infirmary); Dr. D. Beall, for work on sterol metabolism, with special reference to sex hormones (at the Department of Pathology, British Postgraduate Medical School, London); J. G. Chalmers, for work on the role of polycyclic hydrocarbons in experimental tumour production (at the Glasgow Royal Cancer Hospital); Dr. F. C. Courtice, to study the influence of insulin and endocrine secretions on the metabolism of prolonged muscular exercise (at the Physiology Laboratory, Oxford); H. Davson, to study the cause of primary chronic glaucoma of the eye) at the Department of Physiology and Biochemistry, University College, London; Dr. T. R. R. Mann, for research on intracellular compounds of blood pigment and the metabolism of oxalic acid in mammalian tissue (at the Molteno Institute, Cambridge); Dr. Antoinette Pirie, to study the metabolism of filterable organisms by analysis of their enzyme systems (at the Institute of Biochemistry, Cambridge); Dr. D. Richter, for work on the action of adrenaline and related substances on the metabolism of individual organs (at the Institute of Biochemistry, Cambridge).

\section{Travelling Fellowships in Tuberculosis}

The Medical Research Council has awarded Dorothy Temple Cross research fellowships to the following, who intend to study problems of tuberculosis at centres abroad, during the academic year 1937-38 : Dr. B. C. Thompson, formerly assistant tuberculosis officer, Durham County Council (renewal of present fellowship for three months); R. H. R. Belsey, resident surgical officer, Hospital for Consumption and Diseases of the Chest, Brompton, London; Dr. B. M. Maxwell, senior assistant medical officer, Cheshire Joint Sanatorium, Market Drayton ; 0. S. Tubbs, chief assistant to a Surgical Unit, St. Bartholomew's Hospital, London; Dr. Enid M. Williams, assistant lecturer in tuberculosis, Welsh National School of Medicine, Cardiff.

\section{British Empire Cancer Campaign}

THE quarterly meeting of the Grand Council of the British Empire Cancer Campaign was held on July 12. On the recommendation of the Scientific Advisory Committee, the following grants were approved: $£ 500$ to Dr. P. M. F. Bishop, at Guy's Hospital, for the expenses for one year of certain investigations in regard to endocrine therapy in relation to cancer; $£ 250$ to Prof. G. I. Finch, at the Imperial College of
Science and Technology, for the expenses of an investigation, on behalf of the Scientific Advisory Committee, into the nature and structure of carcinogenic compounds ; and $£ 160$ to Dr. P. R. Peacock, at the Glasgow Royal Cancer Hospital, for the purchase of special apparatus for the continuation of his cancer research. On the recommendation of the Joint Committee of the Campaign and of Mount Vernon Hospital, Dr. G. Cranston Fairchild was reappointed the William Morris research fellow in radiology at that Hospital for a further period of one year. The William Morris research fellowship was established five years ago by a generous donation of a capital sum of $£ 25,000$ by Lord Nuffield.

\section{Occultations of Mars and Venus}

If the evening sky is clear on July 17, an interesting observation can be made without a telescope (though, preferably, slight optical aid is desirable) of the occultation of the planet Mars by the moon. The disappearance of Mars, as seen from a station near Greenwich, takes place at the moon's dark limb (the age of the moon being $9 \cdot 7$ days) at position angle $53^{\circ}$ from the north point of the disk, measured eastwards, at $21^{\mathrm{h}} 13^{\mathrm{m}}$ U.T. $\left(22^{\mathrm{h}} \mathrm{I} 3^{\mathrm{m}}\right.$ Summer Time). The reappearance of Mars at the moon's bright limb is at position angle $326^{\circ}$ at $22^{\mathrm{h}} 10^{\mathrm{m}}$ U.T. or $23^{\mathrm{h}} 10^{\mathrm{m}}$ Summer Time. The apparent diameter of Mars is about $14^{\prime \prime}$ and its stellar magnitude $-0 \cdot 8$. A map in the B.A.A. Handbook for 1937 gives the limits on the earth's surface of the visibility of this occultation. The occultation of Venus by the moon on August 3 takes place in full daylight and cannot, in any event, be seen from southern England. The southern limit of visibility of partial occultation, as given in J. Brit. Ast. Assoc., March, p. 187, runs approximately between Hull, Bradford and a little north of Blackpool; the southern limit of total occultation runs from just south of Bridlington, to Borough Bridge and just north of Carnforth. At Edinburgh, the disappearance of Venus is due at $8^{\mathrm{h}} 26^{\mathrm{m}}$ U.T. at position angle $159^{\circ}$ from the north point of the moon's disk, and the reappearance at position angle $212^{\circ}$ at $9^{\mathrm{h}} 1^{\mathrm{m}}$ (add $1^{\mathrm{h}}$ to convert to Summer Time). The phenomenon will require telescopic aid generally, though Venus can on occasions be 'picked up' in daylight by keen-sighted observers. The moon's age is 26.2 days, so that the crescent is a very narrow one. Venus is in its gibbous phase, the ratio of the illuminated area of the disk to that of the entire apparent disk (17" in diameter) being $0 \cdot 67$. Its stellar magnitude is $-3 \cdot 6$. The position of Venus on August 3 at $9^{\text {h }}$ is R.A. $5^{\mathrm{h}} 53^{\mathrm{m}} \cdot 0 ;$ Dec. $+21^{\circ} 20^{\prime}$.

\section{A New Comet (I937 f)}

A NEW comet was discovered on July 4 not far from the star, $\beta$ Persei (Algol), by Mr. Finsler at Zurich. At discovery, the comet was diffuse without a central condensation of nucleus, but two days later, according to an observation made at Barcelona, a nucleus was observed as well as a short tail somewhat more than $1^{\circ}$ in length. The International 